\title{
POST-PUBERTAL REPRODUCTIVE PERFORMANCE OF FRIESIAN HEIFERS FED DIET CONTAINING PROTECTED PROTEIN
}

\author{
M.A. Abu El-Hamd ${ }^{1}$, A.M. Abdelhamid ${ }^{2}$, A.E. Abdel-Khalek ${ }^{2}$ and O. A. \\ El-Kot ${ }^{1}$
}

1- Animal Production Research Institute, Agricultural Research Center, Egypt, 2- Department of Animal Production, Faculty of Agriculture, Mansoura University, Egypt

\section{SUMMARY}

A total of 20 Friesian heifers having live body weight (LBW) of $193.5 \mathrm{~kg}$ and 8-10 months of age were divided into two similar groups, 10 animals in each. Heifers in the first group (G1) were fed untreated concentrate feed mixture (CFM), while those in the $2^{\text {nd }}$ group (G2) were fed CFM treated with $1 \%$ formaldehyde-treated on basis of $C P$ content. Results revealed that the effect of dietary treatment on $L B W$ of heifers at puberty, $1^{\text {st }}$ service and conception was insignificant. Age at puberty and age at first service occurred earlier $(P<0.05)$ by 33.5 and $55(P<0.01)$ days in $G 2$ than in G1. Age at conception was earlier $(P<0.001)$ in $G 2$ (515 days) than in $G 1$ (603 day). Total protein, albumin and globulin concentration increased significantly and creatinine and urea- $N$ in plasma of heifers at puberty decreased significantly in $G 2$ as compared to G1. Ovarian activity was similar in both groups. Interval to progesterone $(\mathrm{Pg})$ peak prior to puberty (26.6 vs. 9 days) and age at $\mathrm{Pg}$ peak (357.3 vs. 389.3 days) were earlier in $G 2$ than in G1. Number of services per conception (1.4 vs. 2.0) and service period (17.0 vs. 20.1 days) were lower $(P<0.05)$ in $G 2$ than G1. Conception rate was higher $(P<0.01)$ in $G 2$ than $G 1$ (100 vs. 70$)$.

The current study concluded that using protected protein in diet of Friesian heifers might gain earlier age at puberty and better reproductive performance with no adverse effect on blood parameters in Friesian heifers.

Kaywords: Heifers, protected protein, blood, ovarian activity, Progesterone, Reproductive performance

\section{INTRODUCTION}

Covering the nutritional requirement of farm animals comes in the priority of herdsmen. The beneficial effects of protected protein were reported on production of lactating cows (Abd El-Maksoud, 1990 and El-Ayek et al., 1999) and on reproductive performance of bulls (Abdel-Khalek et al., 1999). Diets high in ruminally degradable intake protein have been shown to be detrimental to reproduction (Canfield et al., 1990) of dairy cows. However, protein supplements with a high potential for rumen escape have been shown to improve reproduction when fed in excess of NRC recommendations (Wiley et al., 1991). Moreover, feeding undegradable protein diets was reported to improve conception rates, reduce

Issued by The Egyptian Society of Animal Production 
number of services required per conception and shorten days open of dairy cow (Armstrong et al., 1990).

Therefore, this study was undertaken to evaluate the effect of feeding protected protein diets during pre-pubertal ages on pubertal age of Friesian heifers and in turn shortening age at first service to improve reproductive performance of Friesian heifers.

\section{MATERIALS AND METHODS}

The study was carried out at Sakha Animal Production Research Station, belonging to the Animal Production Research Institute, Agricultural Research Center, Ministry of Agriculture, in cooperation with the Animal Production Department, Faculty of Agriculture, Mansoura University, Egypt during the period from November 2004 to March 2006.

\section{Animals}

A total of 20 Friesian heifers having average live body weight of $193 \pm 5 \mathrm{~kg}$ and had age between 8 and10 months was used in this study. At the beginning of the experimental period, animals were divided into two similar groups, each of 10 heifers, based on their body weight and age. Heifers in the $1^{\text {st }}$ group (G1) were fed untreated concentrate feed mixture (CFM), while those in the $2^{\text {nd }}$ group (G2) were fed CFM treated with formaldehyde. All heifers were free of diseases, and had a good health condition. Heifers were housed in two separated semi-open sheds, partially roofed.

\section{Feeding system and management}

The CFM used in feeding heifers of both groups was composed of $37.5 \%$ yellow corn, $20 \%$ soybean meal, $15 \%$ corn gluten, $22.5 \%$ wheat bran, $3 \%$ molasses, $0.5 \%$ premix and $1.5 \%$ common salt. Heifers in both groups were fed equal amounts of a diet containing CFM, rice straw (RS) and fresh berseem (Trifolium alexandrinum) during the interval from November to April (green feeding) or berseem hay $\left(2^{\text {nd }}\right.$ and $3^{\text {rd }}$ cuts) during the interval from May to October (dry feeding) according to the NRC (1984) allowances for dairy heifers. Chemical composition of representative samples of different feedstuffs was determined according to A.O.A.C. (1980) as shown in Table (1).

\section{Protection procedure}

The CFM was treated with commercial (38-40\%) formaldehyde solution at the rate of one $\mathrm{ml}$ formaldehyde per $100 \mathrm{~g}$ crude protein in CFM according to the method described by Ferguson et al. (1967).

\section{Experimental procedures \\ Blood sampling}

Blood samples were collected morning before feeding from the jugular vein into heparinized clean test tubes. At puberty, $1^{\text {st }}$ service and conception, one portion of each collected blood sample was left as whole blood for haematological parameters, while another portion was centrifuged at $15 \mathrm{~g}$ for $10 \mathrm{~min}$ to separate blood plasma, which was kept frozen at $-20{ }^{\circ} \mathrm{C}$ until chemical analyses. 
Table 1. Chemical composition of the experimental feeds (DM)

\begin{tabular}{|c|c|c|c|c|c|}
\hline \multirow{3}{*}{ Item } & \multicolumn{5}{|c|}{ Chemical composition (\%) } \\
\hline & \multicolumn{2}{|c|}{ CFM } & \multirow{2}{*}{$\begin{array}{l}\text { Rice } \\
\text { straw }\end{array}$} & \multirow{2}{*}{$\begin{array}{c}\text { Fresh } \\
\text { berseem }\end{array}$} & \multirow{2}{*}{$\begin{array}{c}\text { Berseem } \\
\text { hay }\end{array}$} \\
\hline & G1 & G2 & & & \\
\hline Dry matter (DM, \%) & 90.42 & 90.12 & 89.24 & 15.26 & 88.23 \\
\hline Organic matter, OM & 90.24 & 90.32 & 83.22 & 86.15 & 88.58 \\
\hline Crude protein, $\mathrm{CP}$ & 16.04 & 16.03 & 1.59 & 14.71 & 14.41 \\
\hline Crude fiber, $\mathrm{CF}$ & 10.96 & 10.89 & 37.21 & 24.9 & 24.67 \\
\hline Ether extract, EE & 4.91 & 5.01 & 1.47 & 2.90 & 6.04 \\
\hline $\begin{array}{l}\text { Nitrogen free extract, } \\
\text { NFE }\end{array}$ & 58.33 & 58.39 & 42.95 & 43.64 & 43.46 \\
\hline Ash & 9.76 & 9.68 & 16.78 & 13.85 & 11.42 \\
\hline
\end{tabular}

Hematological parameters including count of red blood cells (RBC) and white blood cells (WBC), packed cell volume (PCV\%) and hemoglobin ( $\mathrm{Hb}$ ) concentration were determined using fully digital haematology counter (Laboratories, USA). However, total protein (Gornall et al., 1949), albumin (Weichselaum, 1946), urea-N (Patton and Crouch, 1977), creatinine (Henry, 1965) concentrations and activity of AST and ALT (Reitman and Frankal, 1957) in blood plasma were estimated using commercial kits (Diagnostic System Laboratories, Inc., USA). Globulin concentration was calculated by subtracting concentration of albumin from total proteins.

Blood samples were collected twice weekly (at 3-4 days interval) starting at 11 months of age up to conception from six animals in each group (three conceived and three non-conceived in G1 and six conceived animals in G2) for determination of Pg concentration in blood plasma. All blood samples in G2 were taken from conceived animals, where conception rate was $100 \%$.

At 1.5 months prior to puberty, average concentration of $\mathrm{Pg}, \mathrm{Pg}$ peak and interval from Pg peak to puberty was determined in blood plasma. Also, during ovarian cycles from puberty to conception, average concentration of $\mathrm{Pg}, \mathrm{Pg}$ peak within each cycle and interval to Pg peak from starting the ovarian cycle were estimated.

\section{Detection of puberty (first oestrus)}

At 11 months of age, oestrus was checked using teaser male both groups for three times daily (20 minutes each) at 6:00, 12:00 and 15.00 h to recognize heifers on heat. Heifers were considered to reach puberty if they displayed receptive response to teaser and stood for mounting. The onset of first oestrus was used as an indicator for the onset of puberty. At that time heifers were weighed to determine live body weight at puberty.

\section{Service}

Heifers reaching LBW between 340 and $>350 \mathrm{~kg}$ providing display oestrous behaviour were artificially inseminated and heifers were weighed to determine a LBW at the $1^{\text {st }}$ service. This procedure was repeated for heifers that showed oestrous 
signs after the $1^{\text {st }}$ service. Conception was performed by rectal palpation 60 day postinsemination. In animal returned to oestrus after $1^{\text {st }}$ service, number of services per conception (NSC) and service period length (SP) were recorded and LBW at the followed conceived service was considered as LBW at conception. Number and length of oestrous cycles from puberty up to conception were recorded.

\section{Progesterone assay}

Direct radioimmunoassay technique (RIA) was performed for determination of progesterone concentration in blood plasma using ready antibody coated tubes kit (Diagnosis Systems Laboratories Texas, USA) according to the procedure outlined by the manufacturer.

According to the manufacture's information, the cross reaction of progesterone antibody (at 50\% binding), was $100 \%$ with progesterone while it was $6.00,2.50$, $1.20,0.80,0.48$, and $0.10 \%$ with $5 \alpha$-pregnone-3, 20-dione 11-Deoxycorticosterone, $17 \alpha$-Hydroxyprogesterone, 5 $\beta$-pregnone-3, 20-dione 11-Deoxycortisol, and 20 $\alpha$ Dihydroxyprogesterone, respectively and less than $0.1 \%$ with any other steriods.

The standard curve of progesterone ranged from 0.0 to $60.0 \mathrm{ng} / \mathrm{ml}$. The theoretical sensitivity or minimum detection limit, that differed significantly from the $0 \mathrm{ng} / \mathrm{ml}$ standard, was $0.12 \mathrm{ng} / \mathrm{ml}$. The intra and inter-assay coefficients of variation were $8.0 \%$ and $13.1 \%$, respectively, calculated from 16 assays each of $100 / 500$ tubes.

\section{Statistical analysis}

Results were statistically analyzed according to Snedecor and Cocharn (1982). The statistical model was: $Y_{i j}=U+A_{i}+e_{i j}$. Where: $Y_{i j}=$ Observed values, $U=$ Overall mean, $A_{i}=$ groups, $e_{i j}=$ Random error.

\section{RESULTS and DISCUSSION}

\section{Puberty characteristics}

\section{Live body weight and age}

The effect of dietary treatment on live body weight of heifers at puberty was insignificant (Table 2). It is worthy noting that $80 \%$ of the heifers in G1 reached puberty having LBW less than $300 \mathrm{~kg}$. The corresponding percentage in G2 was only $60 \%$.

The present results are close to that reported for LBW at puberty of Hereford $\mathrm{x}$ Friesian heifers $(308 \mathrm{~kg}$ ), as reported by Moran et al. (1990), while less than that reported $(337 \pm 30 \mathrm{~kg})$ by Honaramooz et al. (1998).

Puberty age was significantly $(\mathrm{P}<0.001)$ earlier by about 33.5 days for heifers of G2 than G1 (Table 2). The earlier age at puberty was mainly attributed to that $80 \%$ of heifers in G2 showed their first oestrous within 350-400 days, vs. $70 \%$ of heifers in G1 showed their oestrous activity at age of 400-450 days (Table 2).

Puberty age in G1 (385 days) is similar to that reported by Honaramooz et al. (1998) for cattle heifers, and higher than that reported for Hereford x Friesian heifers (about 352 days) by Moran et al. (1990). In cattle heifers, Hall et al. (1994) recorded that heifers fed high energy level had younger $(\mathrm{P}<0.001)$ age at puberty than those fed regular level. 
Table 2. Live body weight (kg) and age (days) at puberty and its frequency distribution (\%) of heifers in the treated (G2) and control (G1) groups

\begin{tabular}{ccccc}
\hline \multirow{2}{*}{ Item } & \multicolumn{3}{c}{ Dietary groups } \\
\cline { 2 - 5 } G1 & \multicolumn{2}{c}{ G2 } \\
\hline Weight (kg) at puberty & $\mathbf{2 8 2 . 5} \pm \mathbf{1 5 . 9}$ & $\mathbf{2 9 1 . 9} \pm \mathbf{2 1 . 5}$ \\
Frequency distribution (\%) of LBW category $(\mathrm{kg}):$ & No & $\%$ & No & $\%$ \\
$250-299$ & 8 & 80 & 6 & 60 \\
$300-350$ & 2 & 20 & 4 & 40 \\
Age at puberty (days) & $\mathbf{4 1 8 . 4 \pm 6 . 3 ^ { \mathbf { A } }}$ & $\mathbf{3 8 4 . 9} \pm \mathbf{6 . 2}$ \\
Frequency distribution (\%) of puberty age (days): & No & $\%$ & No & $\%$ \\
$350-400$ & 2 & 20 & 8 & 80 \\
$400-450$ & 7 & 70 & 2 & 20 \\
$450-500$ & 1 & 10 & - & - \\
\hline
\end{tabular}

A and B: Means within the same row with different superscripts are significantly different at $\mathrm{P}<0.001$ (insert number of animals). No: Number of animals.

On the basis of these findings, the significantly earlier age at puberty in G2 compared with G1 may be attributed to impact of protected protein diets, which increase the energy available for growth performance of heifers.

\section{Live body weight and age at first service}

Live body weight at first service was not affected by diet (Table 3), while age at first service was earlier $(\mathrm{P}<0.01)$ in $\mathrm{G} 2$ than in $\mathrm{G} 1$ (Table 3). The significant difference in age of heifers at first service between the two groups was due to the frequency distribution of various age categories at first service. In G2, all heifers $(100 \%)$ were served for the first time at age from 450 to 550 days. However, $40 \%$ of heifers in G1 were served for the first time at the same age (Table 3).

Table 3. Live body weight (kg) and age (day) at first service and its frequency distribution (\%) of heifers in the treatment (G2) and control (G1) groups

\begin{tabular}{|c|c|c|c|c|}
\hline \multirow{2}{*}{ Item } & \multicolumn{4}{|c|}{ Dietary groups } \\
\hline & \multicolumn{2}{|c|}{ G1 } & \multicolumn{2}{|c|}{ G2 } \\
\hline Weight at first service (kg) & \multicolumn{2}{|c|}{$380.5 \pm 7.2$} & \multicolumn{2}{|c|}{$389.1 \pm 6.8$} \\
\hline Frequency distribution (\%): & No & $\%$ & No & $\%$ \\
\hline $350-400 \mathrm{~kg}$ & 7 & 70 & 5 & 50 \\
\hline $400-450 \mathrm{~kg}$ & 3 & 30 & 5 & 50 \\
\hline Age at first service (days) & \multicolumn{2}{|c|}{$571.8 \pm 11^{\mathrm{A}}$} & \multicolumn{2}{|c|}{$504.6 \pm 7.2^{\mathrm{B}}$} \\
\hline Frequency distribution (\%): & No & $\%$ & No & $\%$ \\
\hline $450-500$ days & - & - & 4 & 40 \\
\hline $500-550$ days & 4 & 40 & 6 & 60 \\
\hline 550 - 600 days & 3 & 30 & - & - \\
\hline $600-650$ days & 3 & 30 & - & - \\
\hline
\end{tabular}

$\mathrm{A}$ and B: Means within the same row with different superscripts are significantly different at $(P<0.001)$ (insert number of animals). No: Number of animals. 
Live body weight and age at conception

Dietary treatment did not affect LBW at conception (Table 4), where all heifers were conceived at weight $<450 \mathrm{~kg}$. Such trend at conception was associated with nearly similar LBW of heifers at puberty and first service.

Age at conception was earlier $(\mathrm{P}<0.001)$ by 98 days in heifers of $\mathrm{G} 2$ than $\mathrm{G} 1$. Ninety percent of heifers in G2 were conceived between day 450 and 550 of age vs. $20 \%$ in G1 (Table 4).

The earlier age at conception of G2 indicated that age at first conception was about 17 months, which may result in age at the first calving of 26-27 months compared with 29-30 months in G1.

Table 4. Live body weight $(\mathrm{kg})$ and age (day) at conception and its frequency distribution (\%) of heifers in the treatment (G2) and control (G1) groups

\begin{tabular}{ccc}
\hline \multirow{2}{*}{ Item } & \multicolumn{2}{c}{ Dietary groups } \\
\cline { 2 - 3 } & $402.6 \pm 11.9$ & G2 \\
\hline Weight at conception $(\mathrm{kg})$ & & $400.6 \pm 8.1$ \\
Frequency distribution $(\%)$ : & 40 & 30 \\
$350-400 \mathrm{~kg}$ & 60 & 70 \\
$>400-450 \mathrm{~kg}$ & $602.8 \pm 17.8^{\mathrm{A}}$ & $515.2 \pm 12.2^{\mathrm{B}}$ \\
Age at conception (days) & & 40 \\
Frequency distribution $(\%):$ & - & 50 \\
$450-500$ days & 20 & 10 \\
$500-550$ days & 30 & - \\
$550-600$ days & 10 & - \\
$600-650$ days & 10 & \\
$650-700$ days & & \\
A and B: Means within the same row with different superscripts are significantly different at \\
$(\mathrm{P}<0.001)$.
\end{tabular}

\section{Blood parameters}

Haematological parameters

Counts of RBC and WBC were not affected by dietary treatment at puberty, $1^{\text {st }}$ service and conception, except for count of $\mathrm{WBC}$ was greater $(\mathrm{P}<0.01)$ in $\mathrm{G} 2$ than $\mathrm{G} 1$ at $1^{\text {st }}$ service. Averages of $\mathrm{PCV} \%$ was higher in $\mathrm{G} 2$ than G1at puberty $(\mathrm{P}<0.01)$ and conception $(\mathrm{P}<0.05)$, but did not differ between both groups at $1^{\text {st }}$ service. Concentrations of $\mathrm{Hb}$ was higher $(\mathrm{P}<0.01)$ in $\mathrm{G} 2$ than in $\mathrm{G} 1$ only at puberty (Table 5).

The present Improvement in $\mathrm{Hb}$ concentration in blood of heifers fed protected protein diet was reported by El-Serbieney (2000); El-Reweny (1999) and Abu ElHamd (2003).

It is worthy noting that the observed increase in PCV percent in G2 was almost associated with tendency of higher count of RBC in G2 than in G1 at puberty and conception. However, such increase only at puberty was associated with significant increase in $\mathrm{Hb}$ concentration. The pronounced increase in haematological perameters studied of heifers in G2 may be attribute to that protection of dietary protein allows to 
some amino acids to escape from the ruminal fermentation to reach the ileum of the animals fed protected protein diet (El-Reweny, 1990 and Abu-El-Hamd, 2003).

Table 5. Haematological parameters in blood plasma of heifers at puberty, first service and conception in treatment (G2) and control (G1) groups

\begin{tabular}{lccc}
\hline \multicolumn{1}{c}{ Item } & \multicolumn{2}{c}{ Dietary groups } & \multirow{2}{*}{ Sign. } \\
\cline { 2 - 3 } & \multicolumn{1}{c}{ G1 } & G2 & \\
\hline At puberty: & $9.11 \pm 0.31$ & $10.01 \pm 0.42$ & NS \\
Red blood cells $\left(\times 10^{6} / \mathrm{mm}^{3}\right)$ & $12.42 \pm 0.61$ & $12.57 \pm 0.45$ & $\mathrm{NS}$ \\
White blood cells $\left(\times 10^{3} / \mathrm{mm}^{3}\right)$ & $34.28 \pm 0.54$ & $37.80 \pm 0.86$ & $* *$ \\
Package cell volume $(\mathrm{PCV} \%)$ & $8.72 \pm 0.25$ & $10.65 \pm 0.33$ & $* *$ \\
Haemoglobin $(\mathrm{g} / 100 \mathrm{ml})$ & & & \\
At first service: & $9.12 \pm 0.38$ & $9.84 \pm 0.45$ & $\mathrm{NS}$ \\
Red blood cells $\left(\times 10^{6} / \mathrm{mm}^{3}\right)$ & $11.62 \pm 0.48$ & $13.53 \pm 0.51$ & $* *$ \\
White blood cells $\left(\times 10^{3} / \mathrm{mm}^{3}\right)$ & $35.03 \pm 0.56$ & $35.83 \pm 0.74$ & $\mathrm{NS}$ \\
Package cell volume $(\mathrm{PCV} \%)$ & $9.27 \pm 0.24$ & $10.05 \pm 0.34$ & $\mathrm{NS}$ \\
Haemoglobin $(\mathrm{g} / 100 \mathrm{ml})$ & & & \\
At conception: & $9.22 \pm 0.42$ & $10.28 \pm 0.48$ & $\mathrm{NS}$ \\
Red blood cells $\left(\times 10^{6} / \mathrm{mm}^{3}\right)$ & $13.28 \pm 0.30$ & $12.57 \pm 0.58$ & $\mathrm{NS}$ \\
White blood cells $\left(\times 10^{3} / \mathrm{mm}^{3}\right)$ & $35.25 \pm 0.71$ & $38.80 \pm 0.71$ & $*$ \\
Package cell volume $(\mathrm{PCV} \%)$ & $9.50 \pm 0.24$ & $10.03 \pm 0.32$ & $\mathrm{NS}$ \\
Haemoglobin $(\mathrm{g} / 100 \mathrm{ml})$ & & & \\
\hline NS: Not significant & & &
\end{tabular}

NS: Not significant

* Significant at $\mathrm{P}<0.05 * *$ Significant at $\mathrm{P}<0.01$

\section{Biochemical parameters}

At puberty, total protein (TP), albumin (AL) and globulin (GL) significantly increased, while creatinine and urea-N significantly decreased in plasma of G2 than in G1. Similar findings were observed at $1^{\text {st }}$ service, but the differences in GL and urea-N were not significant between G1 and G2. However, at conception, only TP and GL significantly increased, while urea-N decreased $(\mathrm{P}<0.05)$ in $\mathrm{G} 2$ than in $\mathrm{G} 1$. On the other hand, activity of AST and ALT was not affected by dietary treatment at puberty, $1^{\text {st }}$ service and conception (Table 6).

Values of all parameters are within the normal ranges as reported by Metwally et al. (1999) for Friesian calves. The observed improvement in some haematological and biochemical parameters in blood of heifers in G2 compared with G1 may reflect the good health status and heavier weights of heifers in G2 fed treated diet.

The present results concerning the effect of protected protein diet on improving concentration of TP are in agreement with several authors (El-Reweny, 1999; ElSherbieny, 2000 and Abu El-Hamd, 2003), who reported improvement in plasma proteins concentration almost associated with heavy live body weight as affected by feeding animals on protected protein diets, which increases amount of dietary protein and change quality of amino acids.

On the other hand, the marked reduction in concentration of creatinine and urea-N as affected by feeding animals protected protein diet may reflect higher protein efficiency of heifers in G2 than in G1 (Abu El-Hamd, 2003), which may be associate 
with decreased concentration of $\mathrm{NH} 3-\mathrm{N}$ during fermentation in ruminants fed protected protein diet (El-Reweny, 1999 and Abu El-Hamd, 2003).

Table 6. Biochemical parameters in blood of heifers at puberty, first service and conception in treatment (G2) and control (G1) groups

\begin{tabular}{|c|c|c|c|}
\hline \multirow{2}{*}{ Item } & \multicolumn{2}{|c|}{ Dietary groups } & \multirow{2}{*}{ Sign. } \\
\hline & G1 & G2 & \\
\hline \multicolumn{4}{|l|}{ At puberty } \\
\hline Total protein (g/dl) & $7.41 \pm 0.20$ & $8.48 \pm 0.20$ & $*$ \\
\hline Albumin $(\mathrm{g} / \mathrm{dl})$ & $3.75 \pm 0.07$ & $4.09 \pm 0.05$ & $*$ \\
\hline Globulin (g/dl) & $3.66 \pm 0.20$ & $4.39 \pm 0.10$ & $* *$ \\
\hline Creatinine (mg/dl) & $1.79 \pm 0.07$ & $1.45 \pm 0.07$ & $* *$ \\
\hline Urea-N (mg/dl) & $29.58 \pm 1.4$ & $24.05 \pm 1.5$ & $*$ \\
\hline $\operatorname{AST}(\mathrm{IU} / \mathrm{dI})$ & $38.05 \pm 0.90$ & $37.12 \pm 0.90$ & NS \\
\hline $\operatorname{ALT}(\mathrm{IU} / \mathrm{dI})$ & $18.47 \pm 0.55$ & $17.83 \pm 0.48$ & NS \\
\hline \multicolumn{4}{|l|}{ At first service } \\
\hline Total protein $(\mathrm{g} / \mathrm{dl})$ & $7.68 \pm 0.26$ & $8.53 \pm 0.15$ & $*$ \\
\hline Albumin $(\mathrm{g} / \mathrm{dl})$ & $3.55 \pm 0.07$ & $4.04 \pm 0.12$ & $* *$ \\
\hline Globulin $(\mathrm{g} / \mathrm{dl})$ & $4.13 \pm 0.31$ & $4.48 \pm 0.15$ & NS \\
\hline Creatinine $(\mathrm{mg} / \mathrm{dl})$ & $1.79 \pm 0.01$ & $1.49 \pm 0.05$ & $*$ \\
\hline Urea-N (mg/dl) & $35.99 \pm 3.1$ & $30.38 \pm 3.5$ & NS \\
\hline AST (IU/dI) & $37.93 \pm 0.59$ & $37.02 \pm 0.63$ & NS \\
\hline ALT (IU/dI) & $18.40 \pm 0.48$ & $17.30 \pm 0.57$ & NS \\
\hline \multicolumn{4}{|l|}{ At conception } \\
\hline Total protein $(\mathrm{g} / \mathrm{dl})$ & $7.74 \pm 0.11$ & $8.38 \pm 0.16$ & $* *$ \\
\hline $\operatorname{Albumin}(\mathrm{g} / \mathrm{dl})$ & $3.80 \pm 0.10$ & $3.74 \pm 0.12$ & NS \\
\hline Globulin (g/dl) & $3.94 \pm 0.05^{\mathrm{f}}$ & $4.64 \pm 0.07$ & $* * *$ \\
\hline Creatinine $(\mathrm{mg} / \mathrm{dl})$ & $1.89 \pm 0.04$ & $1.75 \pm 0.07$ & NS \\
\hline Urea-N (mg/dl) & $33.78 \pm 1.7$ & $28.17 \pm 1.5$ & $*$ \\
\hline AST (IU/dI) & $38.37 \pm 0.47$ & $37.18 \pm 0.35$ & NS \\
\hline ALT (IU/dI) & $18.68 \pm 0.62$ & $18.05 \pm 0.43$ & NS \\
\hline
\end{tabular}

In accordance with the present reduction in urea-N in blood serum of heifers fed protected protein diet, many authors observed the same trend reported on Friesian calves (Abu El-Hamd, 2003), Friesian bulls (El-Sherbieny, 2000), buffalo calves (Giri and Dass, 1993) and lambs (Mathur et al., 1994) fed by-pass protein diet. Also, the present activities of both transaminases in blood plasma of heifers fed protected protein diet are within the normal values reported for Friesian calves (Metwally et al., 1999 and Abdel-Khalek, 2000). This may reflect the normal physiological status and normal liver function of heifers fed protected protein dirt (Stroev and Makarova, 1989).

\section{Ovarian activity (Number and length of ovarian cycle)}

It is of interest to remember that ovarian cycle length was estimated on the basis of Pg concentration in blood plasma in three animals of each group. Almost similar 
number, length and type of ovulatory cycle from puberty up to conception were observed for both groups. Although total number of ovarian cycles was nearly similar in both groups (16 and 15 for G1 and G2, respectively), the normal cycles were more frequent (almost double) in G1 than in G2 (Table 7).

Table 7 Number and length of ovarian cycles from puberty to conception of heifers in the treatment (G2) and control (G1) groups

\begin{tabular}{ccccccc}
\hline \multirow{2}{*}{ Item } & \multicolumn{6}{c}{ Dietary groups } \\
\cline { 2 - 7 } & \multicolumn{4}{c}{ G1 } & \multicolumn{4}{c}{ G2 } \\
\cline { 2 - 7 } & $\mathbf{N}$ & $\mathbf{n}$ & $\mathbf{X} \pm$ SE & $\mathbf{N}$ & $\mathbf{n}$ & $\mathbf{X} \pm$ SE \\
\hline Ovarian cycle length (days) & 3 & 16 & $22.6 \pm 0.97$ & 3 & 15 & $23.5 \pm 1.55$ \\
Frequency distributions (\%) of ovarian cycles: & & & \\
Short (<19 days) & - & - & - & 2 & 3 & 20.0 \\
Normal (20-23 days) & 3 & 13 & 81.2 & 3 & 7 & 46.7 \\
Long (24-28 days) & 2 & 3 & 18.8 & 3 & 5 & 33.3 \\
\hline
\end{tabular}

$\mathrm{N}$ : Number of animals showing ovarian cycles. $\mathrm{n}$ : Number of ovarian cycles

\section{Progesterone $(\mathrm{Pg})$ profile \\ Prior to puberty}

Results in Table (8) showed that average Pg concentration and Pg peak within 45 days prior to puberty did not differ between the studied groups. However, interval to Pg peak was significantly $(\mathrm{P}<0.05)$ and age at $\mathrm{Pg}$ peak prior to puberty was significantly $(\mathrm{P}<0.05)$ earlier in the treated than in the control group. Similar results were obtained on Friesian heifers by Sherief (2008).

The effect of dietary treatment of G2 on Pg concentration was not reported in the literature, but Lammoglia et al. (2000) found that high-energy diet affected progesterone concentration $(\mathrm{P}<0.05)$.

It could be expected that the short interval to Pg peak prior to puberty in heifers of G2 as affected by feeding on protected protein diet may be the main factor of reaching early puberty.

Table 8. Progesterone concentration $(\mathrm{ng} / \mathrm{ml})$ prior to puberty of heifers in the treatment (G2) and control (G1) groups

\begin{tabular}{cccc}
\hline & N & \multicolumn{2}{c}{ Dietary groups } \\
\cline { 3 - 4 } & & G1 & G2 \\
\hline Average $(\mathrm{ng} / \mathrm{ml})$ & 3 & $0.420 \pm 0.04$ & $0.378 \pm 0.01$ \\
Pg peak $(\mathrm{ng} / \mathrm{ml})$ & 3 & $1.134 \pm 0.26$ & $1.253 \pm 0.22$ \\
Interval to Pg peak (days)* & 3 & $26.67 \pm 12.8^{\mathrm{a}}$ & $9.00 \pm 1.00^{\mathrm{b}}$ \\
Age at Pg peak (days) & 3 & $389.3 \pm 3.90^{\mathrm{a}}$ & $357.3 \pm 7.80^{\mathrm{b}}$ \\
\hline a and b: Group means denoted with different superscripts are significantly different at \\
$(\mathrm{P}<0.05)$ * Interval to Pg peak immediately before puberty incidence $^{2}$
\end{tabular}

\section{During ovarian cycles from puberty to conception:}

Data in Table (9) showed that average Pg concentration within each ovarian cycle was lower $(\mathrm{P}<0.05)$ in $\mathrm{G} 2$ than G1. Sherief (2008) found that average Pg concentration during each ovarian cycle from puberty to conception was lower in 
early than late pubertal Friesian heifers, but the difference was not significant. Heifers in G2 showed longer ovarian cycles. The opposite was observed in heifers of G1.

Table 9. Progesterone concentration of heifers during ovarian cycles from puberty to conception in the treatment (G2) and control (G1) groups

\begin{tabular}{ccc}
\hline \multirow{2}{*}{ Item } & \multicolumn{2}{c}{ Dietary groups } \\
\cline { 2 - 3 } & G1 & G2 \\
\hline Average Pg concentration $(\mathrm{ng} / \mathrm{ml})$ & $2.320 \pm 0.22^{\mathrm{a}}$ & $1.779 \pm 0.014^{\mathrm{b}}$ \\
$\operatorname{Pg}$ peak $(\mathrm{ng} / \mathrm{ml})$ & $5.530 \pm 0.43$ & $4.80 \pm 0.66$ \\
Interval to Pg peak (days)* & $10.625 \pm 0.87$ & $11.200 \pm 0.94$ \\
\hline $\begin{array}{l}\text { a and b: } \\
\text { different at }(\mathrm{P}<0.05) .\end{array}$ & * Interval to Pg peak prior to puberty.
\end{tabular}

\section{Conception rate $(\mathrm{CR})$}

Average number of services/conception and service period were lower in G2 than in $\mathrm{G} 1$. However, $\mathrm{CR} \%$ was higher $(\mathrm{P}<0.01)$ in $\mathrm{G} 2$ than $\mathrm{G} 1(100$ vs. $70 \%)$. This was attributed to that more heifers in $\mathrm{G} 2(60 \%)$ were conceived from the first service vs. $30 \%$ in G1. However, few heifers (20\%) in G1 required two services/conception vs. $40 \%$ in the treatment group. Also, $20 \%$ in the control group required 3 services/conception, while the rest (30\%) failed to conceive (Table 10).

Table 10. Number of services/conception, service period and conception rate of heifers in the treatment (G2) and control (G1) groups

\begin{tabular}{|c|c|c|}
\hline \multirow{2}{*}{ Item } & \multicolumn{2}{|c|}{ Dietary groups } \\
\hline & G1 & G2 \\
\hline Number of services/conception & $2.00 \pm 0.30^{\mathrm{a}}$ & $1.40 \pm 0.22^{\mathrm{b}}$ \\
\hline Service period (days) & $20.1 \pm 0.59^{\mathrm{a}}$ & $17.2 \pm 0.42^{\mathrm{b}}$ \\
\hline \multicolumn{3}{|l|}{ Conception rate $(\%)$} \\
\hline $1^{\text {st }}$ & 30 & 60 \\
\hline $2^{\text {nd }}$ & 20 & 40 \\
\hline $3^{\text {rd }}$ & 20 & -- \\
\hline Total & $70 *$ & 100 \\
\hline
\end{tabular}

\section{CONCLUSIONS}

The current study concluded that using protected protein in diet of Friesian heifers might gain earlier age with appropriate live body weight at puberty and conception, leading to earlier age at $1^{\text {st }}$ calving and inturn increasing animal longevity., In addition, feeding Friesian heifers on protected protein diet may improve healthy status in term of improving haematological parameters and total protein 
concentration in blood plsma as well as improving reproductive performance of Friesian heifers.

\section{REFERENCES}

Abdel-Khalek, A. E.; M. A. El-Harairy; F.E. El-Keraby and M.S. Ahmed, 1999. Reproductive performance of Friesian bulls fed formaldehyde-treated protein diets. J. Agric. Sci. Mansoura Univ., 24: 7269.

Abdel-Latif, M. A., 2005. Nutritional and physiological studies on reproduction in dairy cattle. Ph. D. Thesis, Fac. Agric. Mansoura Univ., Egypt.

Abd El-Maksoud, A.M.S., 1990. Protein solubility and degradability of some treated foodstuff fed to ruminants. Ph. D. Thesis. Fac. of Agric., Fayoum, Cairo Univ., Egypt.

Abu El. Hamd, M.A., 2003. Rumenal development in suckling calves fed protected fat and protected protein. Ph.D. Thesis, Fac. Agric. Mansoura Univ. Egypt.

A.O.A.C., 1980. Official Methods of Analysis. Association of Official Analytical Chemists. the $13^{\text {th }}$ Ed. Washington, USA.

Armsrong, J. D., E.A. Goodall, F.J. Gordon, D.A. Rice and W.J. McCaughey, 1990. The effects of levels of concentrate offered and inclusion of maize gluten of fish meal in the concentrate on reproductive performance and blood parameters of dairy cows. Anim. Prod., 50:1.

Canfield, R. W.; C. J. Sniffen and W. R. Butler, 1990. Effects of excess degradable protein on post partum reproduction and energy balance in dairy cattle. J Dairy Sci., 71:2342.

El-Ayek, M. Y., S.A. El-Ayouty, A. A. Zaki, F. F. Abo-Ammo and A.M. El-Reweny, 1999. Response of growing lambs to feeding on total mixed rations containing formaldehyde-treated soybean meal and linseed meal. J. Agric. Sci. Mansoura Univ., 24: 3804.

El-Reweny, A.A.S., 1999. Studies on evaluation of foodstuffs. Performance of lambs fed total mixed rations containing formaldehyde-treated soybean meal or linseed meal. M. Sc. Thesis, Fac. of Agric., El-Mansoura Univ., Egypt.

El-Sherbieny, M.A.S., 2000. Effect of feeding protected protein diets on reproductive performance of Friesian bulls. M. Sc. Thesis, Fac. of Agric., Mansouura Univ., Egypt.

Ferguson, K.A., J.A. Henslely and P.J. Reis, 1967. Nutrition on wool growth. The effect of protecting dietary protein from microbial degradation in the rumen. Aust. J. Sci., 30:215.

Giri, S.S. and R.S. Dass, 1993. Effect of feeding formaldehyde treated mustard cake on blood metabolites in buffalo calves fed on ammoniated straw. Ind. J. Dairy Sci., 46: 11, 505.

Gornall, A.G., Bardawill, G.J. and M.M. Daved, 1949. J. Biol. Chem. 177:; 751. C. F. Hartmann and Lascelles (1965)

Hall, J.B., K.K. Schillo, B.P. Fitzgerald and N.W. Bradley, 1994. Effects of recombinant bovine somatotropin and dietary energy intake on growth, secretion of luteinizing hormone, follicular development, and onset of puberty in beef heifers. J. Anim. Sci., 72: 709-718.

Henry, R.J., 1965. Clinical chemistry Principles and techics, P. 293. 
Honaramooz, A., R.K. Chandolia, A.P. Beard and N.C. Rawlings, 1998. Excitatory amino acid regulation of gonadotropin secretion in prepubertal heifer calves. Biology of Reproduction, 59: 1124-1130.

Lammoglia, M. A., R.A. Bellows, E.E. Grings, J.W. Bergman, S.E. Bellows, R.E. Short, D.M. Hallford and R.D. Randel, 2000. Effects of dietary fat and sire breed on puberty, weight, and reproductive traits of F1 beef heifers. J. Anim. Sci., 78: 2244-2252.

Mathur, O.P., C.S. Mathur and J.S. Bhatia, 1994. Effect of feeding by-pass protein and urea on certain blood constituents in sheep. International J. Anim. Sci., 9: 2, 261.

Metwally, A.M., E.A. Omar and A.Y. Salem, 1999. Studies on some blood components, rumen fluids and growth as influenced by addition of volatile fatty acids and age of suckling Friesian calves. J. Agric. Res. Tanta Univ., 25 (1).

Moran, C., D.J. Prendiville, J.F. Quirke, and J.F. Roche, 1990. Effects of oestradiol, zeranol or trenbolone acetate implants on puberty, reproduction and fertility in heifers. J. Reprod. and Fertil., 89:527-536.

NRC, 1984. Nutrient Requirement of Beef Cattle ( $6^{\text {th }}$ Ed). National Academy Press, Washington, D. C.

Reitman, A. and S. Frankal 1957. Determination of GOT and GPT in blood serum. J. Clin. Path., 28: 56.

Patton, C.J. and S.R. Crouch, 1977. Determination of urea-N in blood. Anal. Chem., 49: 464.

Snedecor, G.W. and W.G. Cochran, 1982. Statistical Methods. $7^{\text {th }}$ Ed. Iowa Univ. Press, Ames. Iowa, USA.

Speedy, A.W., 1995. Progress in Sheep and Goat Researches. Department of plant Science, Univ- of Oxford U.K.

Stroev, E.A. and V.G. Makarova, 1989. Laboratory Manual Biochemistry, Mir. Mos Cow.

Weichselaum, T.E., 1946. Method for determination of albumin in serum blood. American J. Clin. Pathol., 16: 40.

Wiley, J.S., M.K. Petersen, R.P. Ansotegui and R.A. Bellows, 1991. Production from first-calf beef heifers fed a maintenance or low level of prepartum nutrition and ruminally undegradable or degradable protein postpartum. J. Anim. Sci., 69:42794293. 


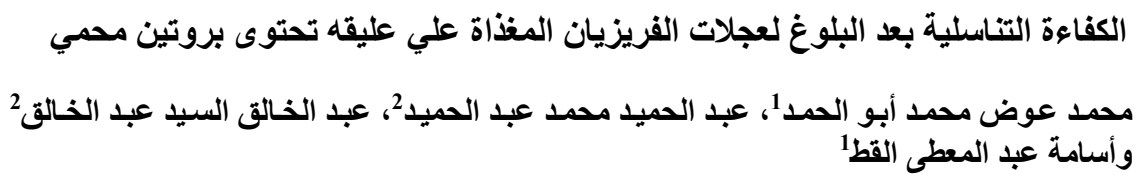

1- معهب بحوث الإنتاج الحيوانسي، مركز البحوث الزراعية، وزارة الزراعة، مصر، 2- قسم إنتاج الحيوان،

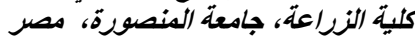

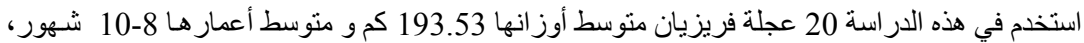

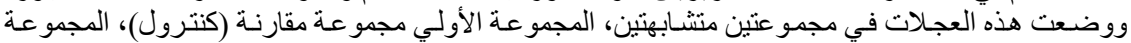

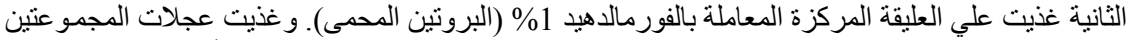

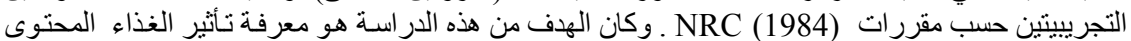

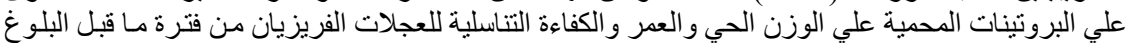

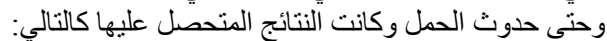

1.لم يتأثر الوزن عندا لبلوغ و عند أول تلقيحه و عند الحمل فى العجلات المغذاه على البروتين المحمي عن

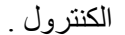

2. انخفض العمر معنويا عند البلوغ وأول بكل تلقيحه فى العجلات المغذاه على البروتين المحمى بمعدل 33.5

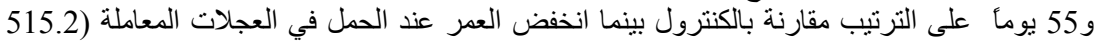

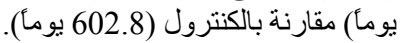

3. وبالنسبة لقياسات الدام فقد ارتفعت قيم كل من

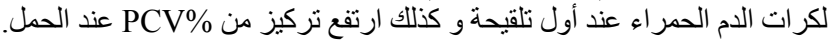

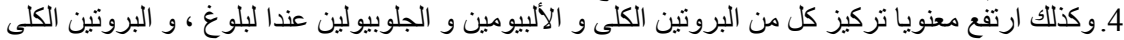

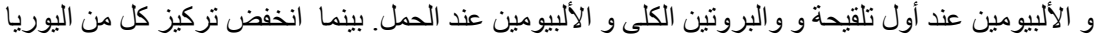

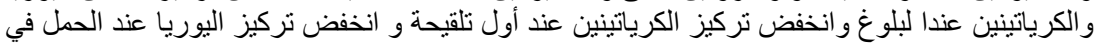

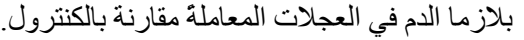

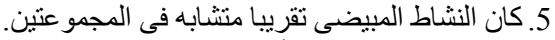

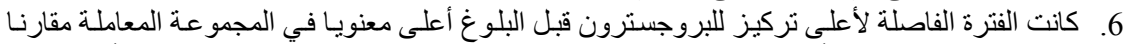

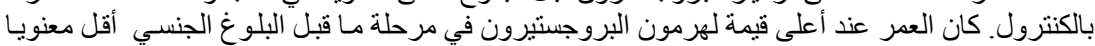

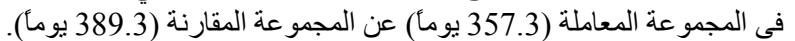

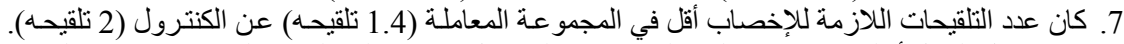

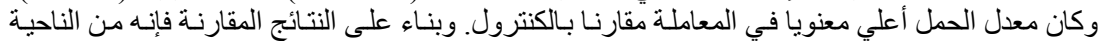

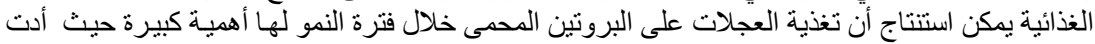
إلي تقليل العمر عند البلوغ أن وحسنت من الكفاءة التناسلية للعجلات الفريز الفيزيان. 